See discussions, stats, and author profiles for this publication at: https://www.researchgate.net/publication/232919698

School memories of young people with disabilities: An analysis of barriers and aids to inclusion

Article in Disability \& Society · March 2010

DOI: 10.1080/09687590903534346

CITATIONS

52

1 author:

Anabel Moriña

Universidad de Sevilla

122 PUBLICATIONS 985 CITATIONS

SEE PROFILE
READS

572

Some of the authors of this publication are also working on these related projects:

Project Inclusive Pedagogy in the University: faculty members's narratives View project

Project Sistema de evaluación indicadores de atención a la diversidad en el ámbito universitario View project 
This article was downloaded by: [Universidad de Sevilla]

On: 12 July 2010

Access details: Access Details: [subscription number 773444422]

Publisher Routledge

Informa Ltd Registered in England and Wales Registered Number: 1072954 Registered office: Mortimer House, 3741 Mortimer Street, London W1T 3JH, UK

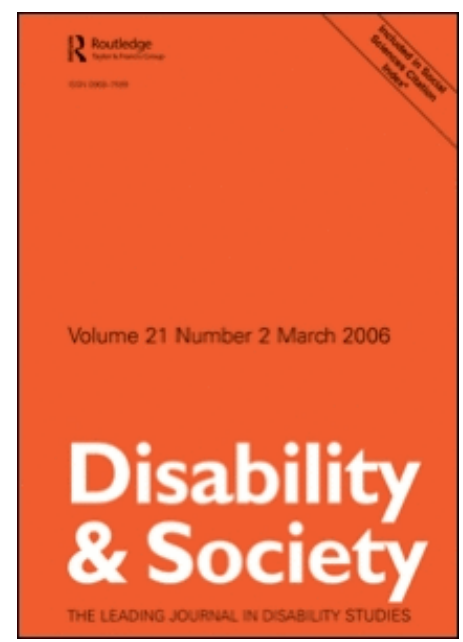

\section{Disability \& Society}

Publication details, including instructions for authors and subscription information:

http://www.informaworld.com/smpp/title $\sim$ content=t713393838

\section{School memories of young people with disabilities: an analysis of barriers} and aids to inclusion

Anabel Moriña Díez ${ }^{\mathrm{a}}$

${ }^{a}$ Departamento Didáctica y Organización Educativa, Facultad de Ciencias de la Educación,

Universidad de Sevilla, 41018 Sevilla, España

Online publication date: 05 March 2010

To cite this Article Moriña Díez, Anabel(2010) 'School memories of young people with disabilities: an analysis of barriers and aids to inclusion', Disability \& Society, 25: 2, 163 - 175

To link to this Article: DOI: 10.1080/09687590903534346

URL: http://dx.doi.org/10.1080/09687590903534346

\section{PLEASE SCROLL DOWN FOR ARTICLE}

Full terms and conditions of use: http://www.informaworld.com/terms-and-conditions-of-access.pdf

This article may be used for research, teaching and private study purposes. Any substantial or systematic reproduction, re-distribution, re-selling, loan or sub-licensing, systematic supply or distribution in any form to anyone is expressly forbidden.

The publisher does not give any warranty express or implied or make any representation that the contents will be complete or accurate or up to date. The accuracy of any instructions, formulae and drug doses should be independently verified with primary sources. The publisher shall not be liable for any loss, actions, claims, proceedings, demand or costs or damages whatsoever or howsoever caused arising directly or indirectly in connection with or arising out of the use of this material. 


\title{
School memories of young people with disabilities: an analysis of barriers and aids to inclusion
}

\author{
Anabel Moriña Díez* \\ Departamento Didáctica y Organización Educativa, Facultad de Ciencias de la Educación, \\ Universidad de Sevilla, C/ Camilo José Cela s/n, 41018 Sevilla, España
}

(Received 21 November 2008; final version received 12 March 2009)

\begin{abstract}
This article presents a selection of the results gleaned from research analyzing the way social exclusion processes are constructed among young adults between the ages of 18 and 25. The paper focuses on a subset of the population studied: young people with disabilities. Likewise, we limit our study to the dimension of schoolrelated experiences. Our research methodology - based on individual personal narratives and first hand accounts - allows a dynamic, participative and integrated approach to the study of exclusion. Participants in the study were asked to reflect on their experiences and, thus, were given a voice. Our specific objective in this article was to identify and explain the barriers and aids to inclusion encountered in a variety of educational environments as expressed by interviewees who had experienced them personally.
\end{abstract}

Keywords: educational exclusion; inclusive education; personal narrative methodology; young people with disabilities

\section{Introduction}

Social exclusion is a complex phenomenon which, in recent years, has increasingly become a priority for international organizations such as the Organisation for Economic Co-operation and Development, World Health Organization, United Nations Educational, Scientific and Cultural Organization and the European Union, among others. These institutions see the struggle against social exclusion as inexorably linked to the successful implementation of socially inclusive policies. Both processes - exclusion and inclusion - can be considered two sides of the same coin, opposite poles of the same continuum. To the degree in which exclusive barriers are brought down, a contribution is made to the creation and consolidation of socially inclusive practices.

One idea suggested by this view is that there is no one kind of exclusion. Rather, exclusion should be discussed in terms of different degrees of non-inclusion which can lead to a variety of personal and collective experiences (Subirats 2004; Tezanos 2001). Exclusion can, from this perspective, be defined as a dynamic, complex, social process entailing the negation of fundamental rights: economic, social, political and educational, among others. It is generally agreed then that socially exclusive mechanisms are multidimensional in nature. Exclusion is a phenomenon involving interacting risk

\footnotetext{
*Email: anabelm@us.es
} 
factors which inevitably mark people's experiences (Atkinson 1998; Kronauer 1998; Tezanos 2001).

There is yet another significant characteristic helping to explain social exclusion: exclusive processes are not circumstantial. The causes leading to situations of noninclusion are structural (Witcher 2003) and exclusion is the direct result of specific social, political, cultural and economic milieux. The social framework itself directly or indirectly generates so-called 'surplus populations'.

This argument was put forth by Oliver (1990), Barton (1996), Shakespeare and Watson (1996), among others, who - from a social model of disability perspective have proposed paradigms for explaining how exclusion is generated. Such social model-based exclusion theories point their finger at practices, attitudes and policies within the social framework as both hindering and helping accessibility and participation in different environments. Hence, there is some degree of consensus regarding the key role economic, educational, social (family and community networks) and workrelated non-inclusiveness plays in generating exclusion (Brandolini and D'Alessio 1998; Kronauer 1998; Levitas 1998; Tezanos 2001).

A close correlation can be found linking social and educational exclusion - the former being more general and the latter more specific. Our review of the literature reveals educational environments to be one of the spheres where exclusion runs most rampant. Macrae, Maguire, and Melbourne (2003) have published findings corroborating the thesis that school-related exclusion can spawn social exclusion in the mid to long term. These authors provided data from recent studies referring to young people considered to be socially excluded or at risk of exclusion. These young people had in common high levels of school absenteeism and limited, or non-existent, academic qualifications, among other characteristics. Howard (1999) shared the notion that social and educational exclusion are closely linked and argued that people with disabilities are among those most vulnerable to exclusive processes. The author justified this line of reasoning, explaining that disabled youth tend to suffer from a more restrictive education than their non-disabled peers, which places them at a disadvantage when it comes to employment and fianancial self-sufficiency.

Conceptually speaking, both social and educational exclusion can be defined as multi-phase processes - complex phenomena triggered by a wide range of factors, behavior patterns and situations (Slee and Alan, 2005). Escudero (2005) identified school failure and drop-out, underachievement, conflictive behavior, etc. as behavioral traits linked to exclusion. Educational exclusion is evident in cases where boys and girls opt to drop out of school, cannot access education or, once in school, find their individual differences (special educational needs, socio-economic/ethnic/gender considerations) are ignored, and where, even having successfully completed their education, they still cannot find their place in society. In short, exclusion can raise its ugly head prior to, during or after the educational phase.

Furthermore, we can identify a gradient continuum spanning the gap between total lack of access to education and full inclusion. Somewhere along this slope we can plot school integration measures, under scrutiny because they fail to guarantee all students equal opportunities for participation in the learning process. This is due to the fact that the principal aim of integration is to reintegrate an individual or group of individuals who have previously been excluded from 'normal life' at school or in the community at large - the presumption being, of course, that the individual or group in question will have to adapt to the given context without challenging existing societal preconceptions and practices. Thus, while integration and inclusion are frequently used 
interchangeably, they can denote divergent courses of action. In theory, inclusion, as a model, is designed to replace integration. The fact is, however, that integration is still the predominant paradigm in schools.

In the Spanish context, the backdrop for the present study,policies and processes aimed at providing 'normal' schooling for girls and boys with disabilities date back to 1985. Current legislation (Ley Orgánica de Educación 2006) calls for educational inclusion although, in practice, schools tend to lean towards integration rather than inclusive educational models. Spanish schools, in other words, have not achieved active learning and participation on the part of all students. Rather, schools continue to employ teaching/learning models designed for the mainstream, marginalizing other students or relegating them to completely separate education tracks.

Inclusive education, on the contrary, can be defined as a process which fosters participation and a sense of belonging for all students and, at the same time, seeks to break down the barriers behind exclusion (Booth and Ainscow 1998). Thus described, inclusion, at school and in society at large, can be seen as a way of life, a unique approach to acting and participating in society, of perceiving others (Sapon-Shevin 1998; Ainscow 1999; Corbett 2001; Slee 2001; Sindelar et al. 2006; Parrilla 2007). From an inclusive perspective then, schools and classrooms are seen as communities which ought to guarantee the right of all students to learn, among their peers, within the framework of a common curriculum.

Within this framework personal narrative methodologies serve well as tools for exposing and denouncing processes of opression, descrimination and exclusion under which certain groups still suffer (Booth and Booth 1996; Goodley 2001). We agree with Owens (2007) regarding the idea that such methodologies can give voice to people and stories traditionally silenced.

Finally, in the particular case of people with disabilities, Tim Booth (1996) explained that the 'excluded voice' thesis - by way of personal narrative methodologies - opens up channels through which we gain access to the perceptions and experiences of opressed groups which lack the authority to make their voices heard via traditional academic channels. Yet other authors (see, for example, Biklen 2000; Tangen 2008) have gone even further to highlight the fact that numerous studies have corroborated that listening to people with disabilities fosters the proliferation of proposals leading to more inclusive educational models.

\section{Research methodology}

The findings presented in this article form part of a larger joint research project at the University of Seville and the University of Cantabria (currently in its final stage) entitled, 'La construcción del proceso de exclusión social en jóvenes: Guía para la detección y evaluación de procesos de exclusión'. The general aim of the study was to analyse the construction of social exclusion (as a personal life experience) among $18-25$ year olds. $^{2}$

The sample population comprised young adults at risk of exclusion, i.e. groups susceptible to non-inclusive processes due to cultural or ethnic factors, disabilities or aspects relating to race or gender. We selected participants according to the following criteria: group diversity, geographical diversity, 18-25 years old. Once these selection criteria had been established the research team embarked on an initial round of informal interviews with a range of associations and institutions aimed at generating a list of potential participants interested in taking part in our study. 
We have employed a personal narrative-based research methodology, thus giving a voice to participants in the study. The study follows a two phase research design. The aim of the first phase was to adopt a descriptive/explicative approach to exclusion processes. It was in turn divided into what we have termed the extensive stage and the intensive stage. Forty-eight young people participated in the extensive stage, which was more desciptive in nature, twelve of whom went on to participate in the intensive stage.

The second phase was a direct result of the previous phase and was in turn divided into two stages or moments, from the moment exclusion indicators were identified to the actual drawing up of a social exclusion detection and evaluation guide.

The data analyzed in the current study consisted of a nine person sample population of disabled young people. At the time of data collection all of the participants were between 22 and 25 years old, with the exception of the three young women who were between 18 and 20 years of age. All participants were people with intelectual, speech and/or hearing, sight or movement-related disabilities. Likewise, selected fragments rather than entire personal narratives are included, as the aim of the study was not to delve into the more global construction of exclusion but rather to analyse one particular exclusion environment: school. Thus, by way of their life stories, emotions and reflections, our young people expressed how they interpreted their own school experience. A transversal analysis ${ }^{3}$ of different key aspects implicit in each participant's case serves as a scaffold to identify and explain the barriers that so often exclude - hindering full access to and participation in social/learning environments as well as those factors which aided participants in their educational struggle.

Following the initial selection of our test group and subsequent informed consent (Sin 2005) by each of the participants, the following data collection methods were employed in each case: self-presentation, biographical interview, picture technique, biogram and life timeline.

The analysis of interviews and transcripts of other documents generated using the methods listed above can be classified as qualitative data analysis in the tradition of the interactive model proposed by Miles and Huberman (1994). This analytical process entails an initial assessment of individual personal narratives across thematic and interpretive categories, followed by the writing up of each life history. Finally, in the second phase of analysis the narratives are compared and contrasted. In particular, the data presented in this article is the result of a transversal analysis of the school environment through the lens of nine personal narratives.

\section{Findings}

In this section we take a closer look at the stories of educational exclusion told by the young people who participated in our study themselves, centering our analysis around five essential points raised by our study of the personal narratives generated: 'parallel' school tracks; 'normal' educational environments which segregate; 'special' educational contexts that bring about disabled students' first experiences in integration; a social life limited to 'special' contexts; a learning paradigm which fails to guarantee equal opportunities for active participation and a sense of belonging for all.

It is not our objective here to extrapolate the opinions and perceptions expressed by the young people we interviewed. The aim, therefore, was not for their voices to speak for others but rather that, by way of a transversal comparative analysis of their experiences in school, their testimony shed light on the barriers and aids the nine 
participants encountered along the way. More specifically, 'barriers' were defined by the interviewees as obstacles to inclusion that impeded or limited learning, a sense of belonging and active participation in educational processes under equal conditions. 'Aids', on ther other hand, include elements of the educational milieu which contribute to social and educational inclusion in the classroom and at school in general. The first-hand testimonies themselves facilitate further reflection on how a wide variety of practices, behaviors and attitudes, generated by a given set of school experiences, influence these young people in their daily lives.

\section{'Parallel' school tracks?}

The schooling phases which the nine young participants in our study had completed were the initial information which helped us to contextualize their experiences. They had in common an educational trajectory which had suffered frequent interruptions. Their stories were different from those of other students of their age. These young people had had to face and adapt to constant changes: attending an integrated school while simultaneously attending support classrooms; changing schools two or more times during the same educational phase; trying to harmonize mainstream education with special educational needs (SEN) environments, etc.

A clear correlation existed with regard to academic achievement. Seven out of the nine participants in our study had reached secondary school. Of those seven, only two had completed compulsory education. ${ }^{4}$ The sole exception was a young woman who was in her last year at university. The option of choice for many of these young people on completing secondary school had been to enroll on what is known in Spain as a Social Guarantee Program (Programa de Garantía Social or PGS) to become anything from hairdressers to housepainters, assistant caregivers, etc. Another popular option was to enroll on occupational training courses (cursos de formación ocupacional) in basic secretarial work or installing air conditioning, etc., targeting disabled students. This is a common trait shared by virtually all the young men and women interviewed: they started out in mainstream educational scenarios but opted to complete their education in special education environments ${ }^{5}$ (participants' personal narratives document the fact that such circumstances are applicable to the workplace and social contexts as well).

\section{'Normal' educational environments which segregate?}

If maybe I had started, they would've put me straight into the special class and I might've had a little less of a bad time. (Sergio)

I personally would've liked to change schools and stay in the special school for deaf people, you know? To have more friends ... but since I had support there [in the mainstream school] I had to put up with it. (Blanca)

One of the most controversial issues appearing over and over in the stories these young people told was the case of a disabled student who was placed in a mainsteam 'integrated' educational environment and, as a result, was doomed to experience the pain and ostracism of segregation. For most, integrated environments have not only failed to offer both social and academic opportunities, but have actually become a barrier to a fulfilling educational trajectory. As they perceive their situation, it seems 
it would have been easier to have completed their education in special environments, as this would have helped them avoid the rejection and discrimination they had experienced in mainstream schools.

The reasons listed above, among others, explain the tendency amoung young people participating in our study to express a negative perception of mainstream integrated environments. As was the case with other young people we interviewed, this next story confirms that a certain degree of labeling and stigmatation took place in the schools they attended. Such marginalizing processes became evident in a variety of different behavior patterns (classroom seating arrangements, absence due to time spent in support classrooms, the use of labels and clichés when referring to SEN students, etc.) which in turn led to identifying difference as a minority attribute. As Corbett (1991) argued, the dominant 'culture' regarding diversity has traditionally been to define difference as negative. This is certainly true in the case of the nine young people we interviewed. The traditional approach to difference was deficiency based, leaving little room for appreciation of diversity.

A: $\quad$ People knew me for my learning disability, just that about me, nothing else.

Q: Are you referring to your classmates?

A: And other students, too ... and the teachers ... you mention my name to the teachers; they all know who I am.

Q: How do you feel about that?

A: How do I feel? Lots of times there've been times, many, when I wanted to be normal, somehow. Why? Maybe to not be noticed, in that sense ... because I didn't want to stand out just for having a learning disability, for being deaf. (Ana)

Paradoxically, as we have already mentioned, 'special' educational environments have, according to the young people themselves, fostered a sense of self-worth, providing opportunities for building self-esteem and encouraging feelings of being 'useful', 'supported' by classmates and teachers alike. For some of those interviewed such experiences gave way to their first fledgling friendships. They preferred, it seems, to find refuge in safe havens such as special schools, where they tended to find a warmer climate devoid of the biased and even hostile attitudinal patterns found in mainstream 'integrated' environments.

The situation described thus far is worrying inasmuch as it represents a considerable paradox in education: the segregation and bias that is rampant in an unknown number of mainstream schools leads to a situation where SEN students and their families seriously question the superiority of 'integrated' environments over 'special' classroom models. A similar situation surfaced in research by Pitt and Curtin (2004), where students participating in a study, after attending mainstream schools for a number of years and going through a string of negative experiences, opted instead to pursue their education in special schools.

\section{'Special' educational contexts that bring about disabled students' first experiences in integration?}

... that's when the support teachers gave me things to do, assignments like all the rest, where I could pull my own weight. And I felt useful, I felt good, I got along with those guys. ... It's like if you take a footballer and then ... out of nowhere ... you put him on Manchester United, for example, and the managers and coaches like the guy, but on a team like that he plays really bad, and then there's this other team, Recreativo de Huelva, 
so they put him on Huelva and he's a star, and so on and so forth,that's where he feels good about his game, on the poorer team, because that's where he makes a difference. (Sergio)

This young man described, albeit in simple terms, an especially alarming situation: special environments like the support classroom, designed to complement inclusive education processes, became an escape for the victims of exclusion perpetrated by mainstream classroom environments. It should come as no surprise then that the majority of participants in our study considered that special educational support environments had been practically the only help they had received in their entire school experience, or that they argued that support classrooms were virtually the only environment in which they had felt they made a difference and were treated as equals. Only in such contexts did they cover the same material and do the same assignments as their classmates, receive the attention and support of their teachers and escape from the humiliation all too frequently associated with mainstream classrooms.

However, at the same time some of the participants in the study openly criticized school planned support activities, which were seen as educational barriers, especially those taking place within the context of the support classroom. Thus, in the case of Ana, Desiré and Blanca (being the only young people we interviewed who attended mainstream classrooms) support efforts only served to reinforce the labeling that was going on in 'normal' classrooms. Moreover, these young women disapproved of the kind of support they received, considering, on the one hand, that the number of teachers assigned to support activities was insufficient and, on the other hand, that support teachers in general were not as professional as might be desired. Along these lines, Blanca referred to a speech therapist who worked at her school and how her efforts to help her improve her language skills were virtually fruitless. Again, from this perspective efforts at integration are a double-edged sword: purportedly at the service of inclusion, what they really tend to perpetrate is segregation and exclusion.

So I asked the speech therapist to help me write compositions and summaries, and she said, 'look, that's not in my job description, my job's to give you photocopies ....' Classes with the speech therapist never meant anything to me because all she ever did was give me a vocabulary worksheet to fill out ... synonyms and antonyms ... you know, the right or wrong kind. I'd look it up in the dictionary and yeah, sure, I'd get the answer but me ... nothing, because you know how to look for words here and you practically don't learn the meaning ... you cross out the word and write it in the gap, that's it. (Blanca)

This brief reflection sheds light on one person's experience in a support classroom, but also situates us face to face with a truly difficult, complex issue. Namely, that the kinds of support the young people in our study have received are contradictory in nature. On the one hand, support environments are spaces for recognition, help and building self-esteem, yet on the other they can be one more cog in the wheel that leads to labeling and marginalization.

\section{A social life limited to 'special' contexts?}

A: They were really mean. My classmates never wanted to be next to me.

Q: Why was that, do you remember?

A: I don't know, they probably thought I looked like a retard or something and didn't want to be seen next to me ... they used to make faces at me. (Desiré) 
A: I wanted to be one of the gang, but they never let me ... sometimes they wouldn't let me. I didn't like the kids that laughed at me because ... they made me feel like a loser, like I'd see it like that kid is laughing at me cause he must be better than me and I'm a nobody.

Q: How did you show them that you wanted to be part of the group?

A: Well I'd go over, you know, to play with them.... I'd try to talk about animals and they'd talk about football, for example.

Q: Could you give me another example?

A: For example, when I was a kid, I didn't know how to run, and lots of times my friends ... when I was 6 , come on, let's play running races ... they raced each other and since I couldn't run good, well they said, ok Sergio, you can't play cause you can't run, yeah, so loud and clear, gosh, I don't know how to run, I can't run with them.

Q: What would you have liked your schoolmates to do for you that they never did?

A: Well, for example, on that issue of when I was a kid that played running races with them ... even the girls used to beat me at racing ... that they would've said, listen, Sergio, even though you can't run you're going to race with us and we're going to run at your level. (Sergio)

In the nine personal narratives analyzed in our study the stories told by the young men and women we interviewed invited us, in every case, to reflect on the fact that the behavior patterns and attitudes prevalent among their peers in mainstream environments had done anything but contribute to more widespread acceptance and inclusion in the classroom. On the contrary, the available data clearly idicates that peer behavior patterns have spurred exclusion in mainstream classrooms. Moreover, this class of 'peer-triggered' barrier is by far the most painful in a long line of hurdles which special needs students struggle to overcome, as it relegates opportunities for social interaction in the classroom and school environments to the sidelines and in effect exiles SEN students to the shadows.

As these young people narrated their experiences, direct discrimination (in myriad forms ranging from sporadic shunning to blatent social isolation) began to manifest itself. At times extrememly negative and even aggressive stigmatization raised its ugly head: parody, insult, aggravation and, occasionally, physical aggression that spilt outside the classroom and stained each and every school and extracurricular environment.

On the other hand, time and again the same personal narratives gave testimony to the crucial role played by their peers in special needs environments when it came to establishing social relationships. It was with these peers that SEN students recovered their self-esteem and began to build a stronger social foundation; through social interaction in special needs contexts these young people learned to feel 'equal' and appreciated and to make their first friends.

Q: Did any of those friends - schoolmates - have a significant impact on your school ... did any of your schoolmates influence you significantly?

A: Mostly at special ed.

Q: Why's that?

A: Just is ... 'cause I discovered I was somebody with them.

Q: Who would you hang out with at recess?

A: With the special ed. people.

Q: Always with them? Why do you think?

A: Because I already felt like them. ... I felt good 'cause I felt like one of them, we did everything together, subtraction, addition, also there were psychological games, we did them together too, I'd go to recess with them ... the things you talk about ... we always talked about the same things, one thing or another, not like 
with my other mates. ... I'd talk about cars and they'd start in about football. (Sergio)

It's like you know everything but something's still missing. Then you go in there (meet a group of deaf people), well you realize it's part of me that's missing, that's still to be discovered. So when I went in there I discovered there were more people like me. And that helps you be stronger - seeing you're not alone - that there are more people ... . (Ana)

\section{A learning paradigm which fails to guarantee equal opportunities for active participation and a sense of belonging for all?}

As we take a closer look at the classroom teaching and learning processes described by these young people three aspects of classroom life emerge: the 'academic' role peers play, the role teachers play and the methodology employed in the classroom.

We have seen in earlier sections that the young men and women participating in this study have not found it easy to develop personal relationships or establish friendships with their mainstream classmates. Here we will hear them denounce the difficulties they have encountered when trying to set up networks for academic cooperation with these same peers. In fact, the most frequently voiced complaint in conversations with SEN students is the complete lack of academic support from mainstream classmates. Sergio's history is a perfect illustration of this. His testimony underscores the situation, revealing the absence of solidarity among his classmates, who only offered to help him on very rare occasions and, it seems, felt that as he was not at the same level academically he should do different tasks.

Me, when I was a kid and maybe I was in my normal class, I'd go up to a classmate from my normal class and, what're you doing?, well, I'm doing some math ... let me see, I want to do some ... I'm going to ask ... no, don't ask the teacher to give you this math, it's too hard for you, ... right there, that was already a barrier that she was putting in front of me, if right then she said yeah, wait a second, I'm going to ask the teacher to give you this math and to help you, that would've been making my life a little easier because she'd be opening doors, but the moment my classmates acted that way with me, even if they didn't mean bad, what happened was that doors shut in my face one after another.

Q: What would you have liked your classmates to do that they never did?

A: That instead of laughing maybe they could say to me, you don't understand but I'll explain it to you. (Sergio)

On the other hand, in the same account Sergio stated that he did receive academic support from his special needs classmates, allowing him to both give and receive help from his peers. Thus, once again, we witness how formal support environments (outside the classroom) provided academic opportunities for these young people.

I felt good there [the SEN classroom] 'cause I felt like one of them, we did everything together, subtraction, addition, also there were psychological games, we did them together too, I'd go to recess with them ... the things you talk about ... we always talked about the same things, one thing or another. (Sergio)

As far as the role played by educators is concerned, the young people interviewed spoke of a virtually non-existent contribution to social and academic inclusion on the part of teachers. This deficit may have manifest itself in the form of teacher passivity in the face of SEN students' needs - the absence of learning activities for a given set 
of students, inflexibility towards adapting teaching methodologies, ignorance of and/ or permissiveness of humiliation and insults from peers, etc. - or surface as excessive, unsolicited attention from teachers.

Q: How did you get along with your teachers?

A: Really bad, and good, both.

Q: Ok, why was that?

A: Because they didn't pay any attention to me sometimes. (Desiré)

For example, the Spanish teacher that gave us loads of notes and all that, and I'd ask her to write slower on the board and she'd say she couldn't waste that much time. Gosh, I can't take it, the light coming in through the window, I just can't do it, and I was fed up already. And if I stopped she'd scold me, so I had to get the notes from my classmates. (Blanca)

When we invited the participants in our study to reflect on those activities and teaching practices which had served to help and support them every single one of them, without exception, agreed that what really helped was when teachers showed an interest in them: dedicating more time to them in class, being patient, having them sit in the front row and providing extra academic support both during and after class.

And what else, oh yeah, I appreciate the good teachers I've had, 'cause they've kept after me, supporting me, saying 'sit in the front row so I can explain things better to you' .... What I remember about them is how patient they were with me ... they'd explain it once to the other kids and 20 times to me. (Sergio)

Lastly, classroom structure and the way in which tasks were carried out were identified as significant barriers for special needs students in mainstream learning environments. With regard to teaching methodology, two scenarios emerged.

(a) Classrooms where only one type of task was assigned to all students, without any effort to adapt assignments to individual learning needs. Activities were not planned with the strategies, methods and support that might be needed in mind, but rather within the framework of a 'one size fits all' (Tomlinson 1995) approach to education.

(b) Classrooms where the presence of students with special needs was 'dealt with' by assigning different tasks, specifically designed for 'special' students, to be carried out in relative isolation from the rest of the class. This was a common model according to the nine participants in our study. Learning was segregated, even physically, and entirely disconnected from what was going on in the rest of the class.

Q: Would you normally do different activities in class?

A: No, the same, we'd copy a book and copy from the book. (Desiré)

He'd sometimes pay attention to me [the teacher], because he was explaining one thing to the 20 students and I was doing something else the teacher assigned me, well sometimes he'd walk around me, Sergio, how's this or that going? (Sergio)

Thus, the young people we interviewed did not help us identify inclusive teaching methodologies which lend themselves to providing for the educational needs of all the students in a given class. However, their voices did invite us to reflect on what inclusion really means and to explore new ways of building inclusive classroom communities. 


\section{A conclusion, of sorts}

A general interpretation of the results of this study could lead one to conlcude that, for these young people, mainstream environments have not facilitated effective learning and socialization processes. On the contrary, the scenarios described by these students have contributed to situations of segregation and discrimination which have marked their school experience. This very same conclusion was reached studies by Conner and Ferri (2007), Shah (2007), Gibson (2006) and Pitt and Curtin (2004).

According to the nine personal narratives analyzed in the present study, special needs students perceived more barriers than boons in their school experience. These young men and women were clearly critical when talking about their memories of mainstream classrooms. In this sense, returning to the notion that mainstream environments have failed to help SEN students find their niche, integrated environments do not provide a positive school experience.

Likewise, the arguments put forth by the participants in the study coincide with several of the principal critiques of the integration model, namely that it has offered little or nothing in the way of going beyond mere physical integration of disabled students in mainstream classrooms. To the extent that this is true, the integration model perpetuates processes of assimilation in the classroom, a reality that is aggravated by the absence of a critical revision of mainstream educational practices.

When students talked about their experiences in special education environments, however, their story changed significantly. Paradoxically, such environments seemed ideal in comparison; it is in these environments that students with special needs got their first taste of 'integration', often playing the role of 'life vest' by providing the support needed to overcome the social, curricular and methodological ostracism imposed upon them in mainstream classrooms. In most cases it was the support classroom which provided a point of reference in rebuilding and getting their school experience back on track. It was here that SEN students managed to boost their selfimage, bandage their broken self-esteem and began to reconstruct their crumbling sense of self. Their first fledgling friendships and social networks sprouted and grew there, where they felt protected, as equals. There too, they felt part of a group empowered to give and receive help from classmates - and able to learn on equal terms with the support of professionals who were sensitive to their needs.

We cannot conclude without pointing out and reflecting on the risk involved in taking such benevolent views of segregated education at face value. Although special educational environments were best when it came to integrating disbled youth, such environments still remained 'special' and therefore tended to segregate. In other words, special environments are 'false' integration contexts. In this sense, normal educational contexts must change; traditional educational practice must be revised and improved in order for all young people to feel safe and welcome; in short, to have a place in an authentically inclusive social and academic community.

Schools must not remain on the sidelines and become accomplices to exclusive educational practices. On the contrary, schools should commit to playing a more active role in denouncing discourse and practice which would legitimize any kind of educational exclusion whatsoever. Setting up special classrooms or parallel tracks which offer students support they do not receive in mainstream classrooms is not a viable path to follow; the only paths worth following are those which lead to truly inclusive education. Naturally, this calls for a restructuring of the way we think about learning and teaching. We should move towards schools in which all students are 
valued, where the goal is to recognize the right of all men and women to an education and to fully fledged participation in that education, schools where the processes and practices holding up the walls of exclusion are brought to a halt.

\section{Notes}

1. 'Constructing social exclusion in young populations: A guide for the detection and evaluation of exclusive processes' (unpublished in English to date), Ministerio de Educación y Ciencia, I+D+I, 2004-07, ref. SEJ 2004-06193-C02-02/EDUC, Ángeles Parrilla and Teresa Susinos, Directors.

2. More detailed information on this research project can be found in Susinos (2007).

3. Transversal analysis as a qualitative methodology is a strategy which allows comparison of different informants and/or methods, concurrent patterns, common themes, overlapping, divergences, etc. relating to the research topic.

4. Compulsory education in Spain spans 6 to 16 years of age. This period comprises two stages: Educación Primaria (Primary School, for children aged 6-11) and Educación Secundaria Obligatoria (Compulsory Secondary School, for ages 12-16). At age 16 (minimum school leaving age) and on completion of the compulsory education phase the Graduado Escolar certificate is obtained.

5. In another part of the article this idea is complemented by the reflections contributed by the young people interviewed for this study.

\section{References}

Ainscow, M. 1999. Understanding the development of inclusive schools. London: Falmer Press.

Atkinson, A.B. 1998. Poverty in Europe. Oxford, UK: Blackwell.

Barton, L. 1996. Disability and society: Emerging issues and insights. London: Longman.

Biklen, D. 2000. Constructing inclusion: Lessons from critical, disability narratives. International Journal of Inclusive Education 4, no. 4: 337-53.

Booth, T. 1996. Sounds of still voices: Issues in the use of narrative methods with people who have learning difficulties. In Sociology and disability, ed. L. Barton. London: Longman.

Booth, T., and M. Ainscow. 1998. Making comparisons: Drawing conclusions. In From them to us, ed. T. Booth and M. Ainscow, 232-46. London: Routledge.

Booth, T., and W. Booth. 1996. Sounds of silence: Narrative research with inarticulate subjects. Disability \& Society 11, no. 1: 55-69.

Brandolini, A., and G. D'Alessio. 1998. Measuring well-being in the functioning space. Rome: Bank of Italy Research Department.

Connor, D.J., and B.A. Ferri. 2007. The conflict within: Resistance to inclusion and other paradoxes in special education. Disability \& Society 22, no. 1: 63-77.

Corbett, J. 1991. So, who wants to be normal? Disability, Handicap and Society 6, no. 3 : 259-60.

Corbett, J. 2001. Supporting inclusive education: A connetictive pedagogy. London: RoutledgeFalmer.

Escudero, J.M. 2005. Fracaso escolar, exclusión social: ¿de qué se excluye y cómo? Profesorado: Revista de Formación del Profesorado 9, no. 1: 1-24.

Gibson, S. 2006. Beyond a 'culture of silence': Inclusive education and the liberation of 'voice'. Disability \& Society 2, no. 4: 315-29.

Goodley, D. 2001. 'Learning difficulties', the social model of disability and impairment: Challenging epistemologies. Disability \& Society 16, no. 2: 207-31.

Howard, M. 1999. Enabling government: Joined up policies for a national disability strategy. London: Fabian Society.

Kronauer, M. 1998. Social exclusion and underclass - new concepts for the analysis of poverty. In Empirical poverty research in a comparative perspective, ed. A. Hans-Jurgen, 51-75. Aldershot, UK: Ashgate.

Levitas, R. 1998. The inclusivity society? Social exclusion and New Labour. London: Macmillan. 
Macrae, S., M. Maguire, and L. Melbourne. 2003. Social exclusion: Exclusion from school. International Journal of Inclusive Education 7, no. 2: 89-101.

Miles, M.B., and A.M. Huberman. 1994. Qualitative data analysis. Beverly Hills, CA: Sage.

Oliver, M. 1990. The politics of disablement. Basingstoke, UK: Macmillan.

Owens, J. 2007. Liberating voices through narrative methods: The case for an interpretative research approach. Disability \& Society 22, no. 3: 299-313.

Parrilla, A. 2007. Inclusive education in Spain: A view from inside. In Policy, experience and change: Cross-cultural reflections on inclusive education, ed. L. Barton and F. Armstrong, 19-36. London: Springer Books.

Pitt, V., and M. Curtin. 2004. Integration versus segregation: The experiences of a group of disabled students moving from mainstream school into special needs further education. Disability \& Society 19, no. 4: 387-401.

Sapon-Shevin, M. 1998. Because we can change the world. Boston, MA: Allyn \& Bacon.

Shah, S. 2007. Special or mainstream? The views of disabled students. Research Papers in Education 22, no. 4: 425-42.

Shakespeare, T., and N. Watson. 1996. Defending the social model. Disability and Society 12, no. 3: 293-300.

Sin, C.H. 2005. Seeking informed consent: Reflections on research practice. Sociology 39, no. 2: 277-94.

Sindelar, P., D.K. Shearer, D. Yendol-Hoppey, and T.W. Liebert. 2006. The sustainability of inclusive school reform. Exceptional Children 72, no. 3: 317-31.

Slee, R. 2001. Organizaciones muy solventes y alumnos insolventes. La política de reconocimiento. In ¿Eficacia para quién?, ed. R. Slee, E. Weiner and S. Tomlinson, 135-52. Madrid: Akal.

Slee, R., and J. Allan. 2005. Excluding the included. In Policy and power in inclusive education. Values into practice, ed. J. Rix, K. Simmons, M. Nind and K. Sheehy. London, UK: RoutledgeFalmer, pp. 13-24.

Subirats, J., ed. 2004. Pobreza y exclusión social. Un análisis de la realidad española y europea. Barcelona, Spain: Fundación 'La Caixa'.

Susinos, T. 2007. Tell me in your own words: Disabling barriers and social exclusion in young persons. Disability \& Society 22, no. 2: 117-27.

Tangen, R. 2008. Listening to children's voices in educational research: Some theoretical and methological problems. European Journal of Special Needs Education 23, no. 2: 157-66.

Tezanos, J.F. 2001. Tendencias de dualización y exclusión social en las sociedades tecnológicas avanzadas. Un marco para el análisis. In Tendencias en desigualdad y exclusión social, ed. J. F. Tezanos, 11-53. Madrid: Editorial Sistema.

Tomlinson, A.C. 1995. How to differentiate instruction in mixed-ability classrooms, 2nd edn. Alexandria, VA: Association for Supervision and Curriculum Development.

Witcher, S. 2003. Reviewing the terms of inclusion: Transactional proccesses, currencies and context. London: Center for Analysis of Social Exclusion. 